\title{
Anti-CD6 Monoclonal Antibody
}

National Cancer Institute

\section{Source}

National Cancer Institute. Anti-CD6 Monoclonal Antibody. NCI Thesaurus. Code C112886.

Any monoclonal antibody directed ag ainst the cell surface glycoprotein CD6, regardless

of the antibody type. 